\title{
Electromechanical battery, electrical machines mass functions analysis
}

\author{
Andrejs Podgornovs (Dr.sc.ing, Riga Technical University), Anton Sipovičs (Mg.sc.ing)
}

\begin{abstract}
In this paper different types of electrical machines in electromechanical battery, were described. The most known manufactured battery data is composed. Three types of machines: synchronous machine with salient poles and electromagnetic excitation, with permanent magnets on rotor and reluctance synchronous machine were analyzed. For all types of machines, mass is function of general geometrical size of magnetic system and machines electrical power.
\end{abstract}

Keywords - Electrical machine, electromechanical battery, machines mass function.

\section{INTRODUCTION}

Energy storage nowadays is important for the national economy, using energy storage applications is possible to enlarge power system stability, improve customer power quality, protecting customers from various types of fluctuations, which adversely affects on the production processes. Energy can be accumulated in different ways, each of them has advantages and disadvantages, and it is possible to store energy in the rotating mass. This method has a long history, but from the end of the 20th century, when appeared new technological possibilities to increase the specific energy per mass unit, it takes a new life, and occupies a significant place among energy storage applications.

\section{ELECTROMECHANICAL BATTERY}

Electromechanical battery store energy in the kinetic form, the storage applications battery is a rotating disk flywheel. There are various flywheel designs, as well as a wide range of materials. For the charging the flywheel with energy and for discharging process is necessary to use electrical machine, in the charging process this machine is working in motor mode, and in the discharge process, it serves as a generator. Stored energy quantity can be found with equation:

$$
W=J \frac{\omega^{2}}{2}
$$

where $\mathrm{J}$ - the flywheel moment of inertia, $\mathrm{kg} \cdot \mathrm{m}^{2}, \omega$ angular velocity, $\mathrm{rad} / \mathrm{s}$.

Equation shows that the accumulated quantity of energy can be increased in two ways, by increasing the rotating mass $\mathrm{J}$, or $\omega$ speed, it more reasonably to increase the speed.

Advantage of the electromechanical battery:

- Capacity does not through lifetime;
- Applications parts don't have dangerous chemical components;

- Lifetime of application is higher then lifetime of other storage applications;

- high charge / discharge cycle quantity;

- Minimal EMA complex maintenance;

- Easy to define charge level, which is proportional to the rotational speed;

- High energy specific energy $\mathrm{kWh} / \mathrm{kg}$, and power $\mathrm{kW} / \mathrm{kg}$ ratio;

- A simple construction;

Electrical machine has main position in EMB, machines type provides the structure and quality indicators of energy storage application. It means that the EMB design is based on the type of electrical machines [1]. In references [1,2] review the main EMB schemes, calculations of this sources show, that collector dc machines, asynchronous machines and all schemes with gear box did not fined place in modern EMB complex. Analyzing the current situation in the EMB, it can be concluded that, thanks to modern power electronics developments, opened the possibility to use new type of electric machines. Various EMB manufacturers, use different types of electrical machines and use it for specific purposes:

- Brake energy accumulation in electric transport (auto or city public transport network);

- Uninterruptible power supply (ensure consumer with energy up to 10 - 15 seconds until the backup generator will be started, as well as extend battery lifetime by working on short-term power supply fluctuations);

- Power system regime improvement (frequency control, the regulation of energy balance);

- Renewable energy power plants (wind power, wind speed fluctuations compensation);

Table 1 shows the EMB manufacturers used electric machines types.

Table 1

\begin{tabular}{|c|c|c|}
\hline Nr. & Company & Electrical machine \\
\hline 1. & Piller & $\begin{array}{l}\text { Synchronous machine, } 2 \mathrm{p}=4, \mathrm{n}=3600 \mathrm{~min}^{-1} \text {, steel } \\
\text { flywheel [3] }\end{array}$ \\
\hline 2. & $\begin{array}{l}\text { AFS Trinity } \\
\text { Power } \\
\text { Corporation }\end{array}$ & $\begin{array}{l}\text { Synchronous machine with permanent magnets } \\
\text { (Hallbach Array), } \mathrm{n}=40800 \mathrm{~min}^{-1} \text {, composite } \\
\text { flywheel [4] }\end{array}$ \\
\hline 3. & $\begin{array}{l}\text { Beacon } \\
\text { Power }\end{array}$ & $\begin{array}{l}\text { Synchronous machine with permanent magnets, } \\
2 \mathrm{p}=4, \mathrm{n}=10000 \mathrm{~min}^{-1} \text {, composite flywheel [5] }\end{array}$ \\
\hline 4. & $\begin{array}{l}\text { Active Power, } \\
\text { Pentadyne }\end{array}$ & $\begin{array}{l}\text { Reluctance synchronous machine, } 2 \mathrm{p}=4 \text {, } \\
\mathrm{n}=52000 \mathrm{~min}^{-1}, \text { composite flywheel [6] }\end{array}$ \\
\hline 5. & Enercon & $\begin{array}{l}\text { Standard (Enercon) synchronous machine, steel } \\
\text { flywheel [7] }\end{array}$ \\
\hline 6. & Vycon & Synchronous machine with permanent magnets, \\
\hline
\end{tabular}


\begin{tabular}{|l|l|l|}
\hline & & $\mathrm{n}=36000 \mathrm{~min}^{-1}$, steel flywheel [8] \\
\hline 7. & Cleanwave ${ }^{\circledR}$ & No contact synchronous machine [9] \\
\hline
\end{tabular}

It can be concluded that today is mainly used high-speed non-contact reversed electrical machines, with goal to reduce application mass. Above are showed machines with a relatively low rate of rotation speed $\left(3600 \mathrm{~min}^{-1}\right)$ which can be applied in urban electrified transport network, where frequently happen charge/discharge process, and for safety improvement we should "pay" with EMB application increased mass. Machine and the flywheel mass is function of rotation speed $m_{F L}=f(\omega), m_{E M}=f(\omega)$ [2]. High-speed machines are designed primarily for uninterruptible power supply, where electrical machinery has rare in charging and discharging.

Types of electrical machines in storage applications: classic design synchronous machine, synchronous machine with permanent magnets on the rotor, and the reluctance synchronous machine, without rotor windings. In the design process of EMB electrical machine, one of the main parameters of a machine is mass, which depends from rotation speed changes in the discharge process. Analyzing EMB mass as a function of rotation speed variation, it can be concluded that exist a rotation speed, which provides mass minimum of storage application [10], without efficiency coefficient analysis.

\section{SyNCHRONOUS MACHINE WITH ELECTROMAGNETIC EXCITATION}

Design steps of synchronous machines is well known, and in EMB designing process is necessary take into account discharge process minimum rotation speed. Main machines restrictions are related to the stator and rotor windings heating, as well as the rotor steel and coil geometric dimensions, which depend on the machines maximum rotation speed in the beginning of the discharge process.

Now is necessary to identify the main relationships, between machines dimensions and rotation frequency, electromagnetic loads (linear current density and air gap magnetic flux density), as well as with other machine parameters. AC machines (internal) power (VA):

$$
S=m_{1} \cdot E_{1} \cdot I_{1}
$$

In equation: $\mathrm{m} 1$ - number of phases, E1 - stator windings phase (electromotive force) EMF for asynchronous motor, synchronous machine $E_{1}=E_{\delta}$, it is the stator winding inducted phase EMF with the resultant magnetic flux in air gap, $\mathrm{I}_{1}$ - stator winding phase currents. Taking into account equations below:

$$
\begin{gathered}
E_{1}=4 \cdot k_{f} \cdot f_{1} \cdot k_{w} \cdot w_{1} \cdot \Phi \\
f_{1}=\frac{p \cdot n_{1}}{60} \\
\Phi=\alpha_{\delta} \cdot \tau \cdot l_{\delta} \cdot B_{\delta}
\end{gathered}
$$

$$
\begin{gathered}
\tau=\frac{\pi \cdot D_{1}}{2 p} \\
A_{1}=\frac{2 m_{1} \cdot w_{1} \cdot I_{1}}{\pi \cdot D_{1}}
\end{gathered}
$$

As a result, power equation (VA):

$$
S=\frac{k_{f} \cdot\left[\omega_{1} \cdot \omega_{2^{*}}\right] \cdot k_{t i n} \cdot \alpha_{\delta} \cdot\left|D_{1}^{2} \cdot l_{\delta}\right| \cdot B_{\delta} \cdot A_{1} \cdot \pi}{2}
$$

In formulas (8) is added new variable $\omega_{2^{*}}$, it is important that the design of EMB electrical machine, it is necessary to calculate at a minimum speed, in the end of the discharge process $\omega_{2}$. In equations: $\mathrm{k}_{\mathrm{f}}$ - field form factor, which shows the ratio between real EMF and its average value, $\mathrm{f}_{1}$ frequency, $\mathrm{Hz} ; \mathrm{k}_{\mathrm{w}}$ - stator winding factor; $\mathrm{w}_{1}$ - turns per phase, $\Phi$ - magnetic flux, $\mathrm{Wb}, \mathrm{p}$ - pole pair number, $\mathrm{n}_{1}$ synchronous rotation speed $\mathrm{rpm}, \alpha_{\delta}$ - relative pole with, which shows the relationship $\frac{B_{\delta_{-} \text {average }}}{B_{\delta \text { max } i m a l}}, 1_{1}$ - stator length, $B_{\delta}$ - the maximum air gap flux density, $A_{1}$ - electric loading of machine; $\mathrm{D}_{1}$ - internal stator diameter. If you look at electric machine in general (stator and rotor) as a cylinder, then:

$$
m_{\text {gen }}=V_{\text {gen }} \cdot \gamma_{t e r}=\frac{\pi \cdot D_{a r}^{2}}{4} \cdot l_{\delta} \cdot \gamma_{t e r}
$$

It can be taken from literature source [4], that the stator diameter factor $k_{D}=\frac{D_{\text {outer }}}{D_{1}}=1.5$, the mass of the generator: $m_{\text {gen }}=\frac{\pi}{4} D_{\text {outer }}^{2} \cdot l_{\delta} \cdot \gamma_{\text {steel }}=\frac{\pi}{4}\left(k_{D} \cdot D_{1}\right)^{2} \cdot l_{\delta} \cdot \gamma_{\text {steel }}$ :

$$
m_{\text {gen }}=\frac{\pi \cdot k_{D}^{2}}{4}\left(D_{1}^{2} \cdot l_{\delta}\right) \cdot \gamma_{\text {steel }}
$$

In the results, if is known discharge power $\mathrm{P}_{\mathrm{d}}$ :

$$
D_{1}^{2} \cdot l_{\delta}=\frac{2 P_{d} \cdot k_{E}}{k_{f} \cdot \omega_{1} \cdot \omega_{2^{*}} \cdot k_{\text {tin }} \cdot \alpha_{\delta} \cdot B_{\delta} \cdot A_{1} \cdot \pi \cdot \cos \varphi}
$$

And the resulting mass of the generator:

$$
\begin{gathered}
\quad m_{\text {gen }}=\frac{k_{D}^{2} \cdot \gamma_{\text {steel }} \cdot k_{E}}{2 k_{f} \cdot k_{w} \cdot \alpha_{\delta} \cdot B_{\delta} \cdot A_{1} \cdot \cos \varphi} \cdot \frac{P_{d}}{\omega_{1} \cdot \omega_{2^{*}}}= \\
=k_{\text {gen }} \cdot \frac{P_{d}}{\omega_{1} \cdot \omega_{2^{*}}}, \\
\text { where } k_{\text {gen }}=\frac{k_{D}^{2} \cdot \gamma_{\text {ter }} \cdot k_{E}}{2 k_{f} \cdot k_{\text {tin }} \cdot \alpha_{\delta} \cdot B_{\delta} \cdot A_{1} \cdot \cos \varphi} .
\end{gathered}
$$




\section{SYNCHRONOUS MACHINE WITH PERMANENT MAGNETS ON ROTOR}

If we analyze design of synchronous machines with permanent magnets in the rotor, then the design has different peculiarities. From the first steps of design, is necessary to take accurate and definite magnetization curve of permanent magnet, a - form factor is different for magnet materials and can not be taken an average value. Rotor permanent magnet selection criterion is the operating temperature, demagnetizing currents that may degrade the properties of the magnet as well as its price, which can greatly increase the price of the electrical machine. In general, from [11] analytical expressions of magnet magnetization curve in second quadrant, formula:

$$
B=\frac{B_{r} \cdot\left(H_{c}-H\right)}{\left(H_{c}-a \cdot H\right)}
$$

Where: $\mathrm{Br}$ - permanent magnet remanence flux density, if the external magnetic field strength $\mathrm{H}=0, \mathrm{H}_{\mathrm{c}}$ - magnetic field coercivity strength, external field strength at which the magnet completely demagnetized and $\mathrm{B}=0$, a - coefficient that reflects the relationship between the magnet $\mathrm{Br}$ and the saturation induction Bs. The coefficient $\mathrm{a}$, is dependent on $\mathrm{B}(\mathrm{H})$ curve form, this form is characterized by a factor of $\gamma$. To understand the role of permanent magnet gamma coefficient analyze energy which is proportional to B and $\mathrm{H}$, in addition there is an optimal $\mathrm{B}_{0}$ and $\mathrm{H}_{0}$ to ensure maximum energy $\gamma=\frac{B_{0} \cdot H_{0}}{B_{r} \cdot H_{c}}$. If magnetization curve form factor $\gamma=0.25$, it is a straight line, if $\gamma>0.25$ the curve is strongly convex, the boundary case $\gamma=1$ magnetization curve is parallel to the $\mathrm{H}$ axis. From [11], $a=B_{r} / B_{s}=\frac{2 \sqrt{\gamma}-1}{\gamma}$.

To analyze mass of the synchronous machine with permanent magnets is necessary to express the mass function equation. Power of the machine from [12] $P=m U I$, where: U - voltage, I - load current, after equation transformation $P=m E_{0} I_{k} k_{u}$, where $\mathrm{E}_{0}-$ no load EMF, $\quad \mathrm{I}_{\mathrm{k}} \quad$ - $\quad$ short-circuit current, $k_{u}=\left[\sqrt{1-(u \cdot \cos \varphi)^{2}}-u \cdot \sin \varphi\right] u$ - coefficient which take into account power factor of and hardness of external characteristic. No load EDS and short-circuit current multiplication completely dependent on the characteristics of permanent magnet, where the $\mathrm{S}$ - factor of the magnet, which will analyzed below, $\mathrm{m}_{\mathrm{e}}, \mathrm{m}_{\mathrm{i}}$ - scale factors which are introduced for $\mathrm{B}(\mathrm{H})$ curves constructing in relative value. To express the machine mass formula, look at the mass scaling factors:

$m_{e}=4.44 \cdot f \cdot w \cdot k_{w} \cdot \frac{B_{r} \cdot S_{m a g}}{k_{f}}, m_{i}=\frac{H_{c} \cdot L_{m a g} \cdot p}{1.35 \cdot k_{d} \cdot k_{w} \cdot w}$ where

$\mathrm{f}$ - frequency, w - phase number of turns, $\mathrm{k}_{\mathrm{w}}$ - winding factor, $S_{\mathrm{mag}}$ - look set pole and one pole of the magnet cross-section, $\mathrm{k}_{\mathrm{f}}$ - field form factor, $\mathrm{L}_{\mathrm{mag}}$ - magnet length of one pole, $\mathrm{p}$ - number of pole pairs, $\mathrm{k}_{\mathrm{d}}$ - rotor reaction factor (salient pole design). By inserting the above shown formulas, machine power equation:

$$
P=m\left[\frac{4.44 \cdot m \cdot f \cdot B_{r} \cdot H_{c} \cdot V_{m} \cdot S \cdot k_{u}}{2 \cdot k_{f} \cdot 1.35 \cdot k_{d}}\right]
$$

In formula: $V_{m}=S_{m a g} \cdot L_{m a g} \cdot 2 p$ - magnet volume, which defines stator inner diameter and other machine dimensions. Permanent magnet volume:

$$
V_{m}=\frac{2 P \cdot k_{f} \cdot 1.35 \cdot k_{d}}{4.44 \cdot m \cdot f \cdot B_{r} \cdot H_{c} \cdot S \cdot k_{u}} .
$$

Now we can find machine volume through diameter ratio $k_{D}=D_{\text {outer }} / D_{1}$, where $\mathrm{D}_{\text {outer }}$ - stator outer diameter, D1 - stator inner diameter. Also is necessary to define the filling of rotor with permanent magnets, through the fill factor

$$
k_{\text {fiel }}=\frac{V_{m}}{V_{\text {rot }}}=\frac{V_{m}}{\left(0.25 \pi D_{1}^{2} \cdot l_{\delta}\right)}
$$

Where: $1_{\delta}$ - stator length. Assuming that the machine capacity:

$$
V_{m}=\frac{\pi \cdot k_{D}^{2} \cdot D_{1}^{2} \cdot l_{\delta}}{4}
$$

and subject to the permanent magnet volume,

$$
V_{m}=\frac{k_{D}^{2} \cdot V_{m}}{k_{\text {rot_aizp }}}=\frac{k_{D}^{2} \cdot 2 P \cdot k_{f} \cdot 1.35 \cdot k_{d}}{k_{\text {rot_aizp }} \cdot 4.44 \cdot m \cdot f \cdot B_{r} \cdot H_{c} \cdot S \cdot k_{u}}
$$

Analyzing (18) equation, it can be concluded that using of magnets with high-energy parameters can achieve a reduction of machine dimensions. One of the main conclusions is that, in principle, machine dimensions are independent from the speed of rotation, and a big machine with a big number of poles will have the same mass as high-speed machine. This conclusion is not really correct, because in order to ensure a mass of high-speed machines, in multi pole machine greatly increased the electric loading - A. From literature source [11] is known that the synchronous machines with permanent magnets has a higher pole pair number $\mathrm{p}>3-4$, compared with the same machine with an electromagnetic excitation. Formula (18) shows that the mass depends on the coefficient S, which depends on the machine magnet parameters: dispersion magnetic flow, air gap flow, external magnetic circuit configuration. From [12] is known, greater $\mathrm{S}$ factor provides, the better using of permanent magnets. $\mathrm{S}$ factor analytical expression: 


$$
\begin{array}{r}
S=\left[\frac{1+\operatorname{tg} \alpha_{k}-\sqrt{\left(1+\operatorname{tg} \alpha_{k}\right)^{2}-4 a \cdot \operatorname{tg} \alpha_{k}}}{2 a \cdot \operatorname{tg} \alpha_{k}}\right]^{2} . \\
\cdot \frac{\left(\operatorname{tg} \beta+\operatorname{tg} \alpha_{k}\right)\left(1-\operatorname{tg} \alpha_{k} \operatorname{tg} \alpha_{0}\right)}{1+\operatorname{tg} \alpha_{0} \cdot \operatorname{tg} \beta}
\end{array}
$$

Where $\operatorname{tg} \alpha_{\mathrm{k}}$ - magnetic conductivity at fault, and $\operatorname{tg} \alpha_{0}-$ at no load, $\operatorname{tg} \beta$ - return the tangent of the curve angle, as well as already described coefficient - a. Analyzing formula (19), is clear that there are certain $\alpha_{k}$ which is providing the maximum coefficient $\alpha_{0 \text { opt }}$ (Fig. 1.).

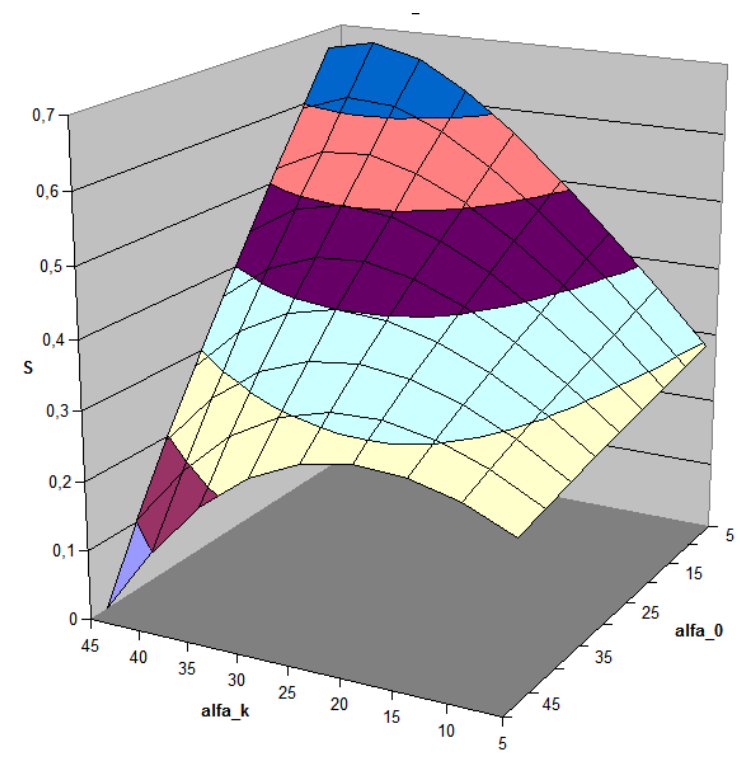

Fig. 1. Synchronous machine with permanent magnets, $S$ factor values at different $\operatorname{tg} \alpha_{k}, \operatorname{tg} \alpha_{0}$, which describes the machine magnetic systems.

Every material has a variable combination that ensures maximum use of magnet material.

\section{RELUCTANCE SYNCHRONOUS MACHINE}

Next synchronous machine, which mass will be calculated is a reluctance synchronous machine. These machines differences from the described above, rotor without excitation windings contact coils, salient poles rotor. Machine is excitation occurs by the stator current reactive components, which is consumed from the network. This current component creates longitudinal magnetic flux, which is also machine excitation flow. From the classical synchronous machines power equations:

$$
\begin{array}{r}
P_{m}=m \frac{E_{0} U}{x_{d}} \sin \Theta+m \frac{U^{2}}{2}\left(\frac{1}{x_{q}}-\frac{1}{x_{d}}\right) \sin 2 \Theta= \\
=P_{m 0}+P_{\text {mpap }}
\end{array}
$$

In equation: $\mathrm{E}_{0}-\mathrm{EMF}, \theta$ - angle between voltage $U$ and EMF E vectors, $\mathrm{x}_{\mathrm{d}}$ and $\mathrm{x}_{\mathrm{q}}$ - direct and quadrature - axis components of stator reactance, $\mathrm{P}_{\mathrm{m} 0}-$ main power, $\mathrm{P}_{\mathrm{mpap}}-$ eddy power.

For the reluctance machine, power equation is:

$$
P_{m}=m \frac{U^{2}}{2}\left(\frac{1}{x_{q}}-\frac{1}{x_{d}}\right) \sin 2 \Theta
$$

$P_{\text {mpap }}$ (in (22)) is independent from the $i_{\text {ier }}\left(E_{0}=f\left(i_{\text {ier }}\right)\right)$, if $i_{\text {ier }}$ $=0$ and $\mathrm{U} \neq 0, \mathrm{P}_{\mathrm{m} 0}=0, \mathrm{P}_{\text {mpap }} \neq 0 . \mathrm{P}_{\text {mpap }}$ occur only in machine with salient poles $\left(\mathrm{x}_{\mathrm{d}} \neq \mathrm{x}_{\mathrm{q}}\right)$, and reaches its maximum at $\theta=45^{\circ}$ [13].

Analyzing reluctance synchronous machine rotor design, can be mentioned that the main task is $x_{d} \neq x_{q}$, and $x_{d}>x_{q}$. From [14] machine power factor $\left(\mathrm{L}_{\mathrm{d}}, \mathrm{L}_{\mathrm{q}}\right.$ - direct and quadrature - axis components of stator inductance:

$$
\cos \varphi=\frac{L_{d} / L_{q}-1}{L_{d} / L_{q}+1} .
$$

Using the classical salient poles rotor, induction ratio reaches $L_{d} / L_{a}=2-3$. Using special air barriers in rotor for magnetic flux can reduce the hardness of the rotor, and limits the maximal speed [14]. Today use rotor design with the magnetic and non-magnetic material layers arranged in the direction of rotation axis. In rotor construction are two materials: electro technical steel and aluminium. In this way achieved high longitudinal conductivity and relatively low conductivity in cross direction. Aluminium layers serve as a squirrel cage in induction motor rotor, and provide start-up torque, and pull synchronous machines in synchronism. Machine layer rotor design significantly improves power factor and improve the mass dimensions [12]. Cylindrical shape of the rotor reduces aerodynamic losses. Compared to the rotor with permanent magnets, reluctance machines rotor is insensitive to high temperatures, no loss of the stator magnetization in storage application standby mode. Reactive synchronous machines have the same problems that asynchronous generator in order to work on the isolated load capacitors are required, which serve as reactive energy sources. Determining reluctance synchronous machine main dimensions can be used machines constant equation [15]. From [16] Arnold machinery constant:

$$
C_{A}=\frac{D_{a}^{2} l_{\delta} n}{P_{e m}}=\frac{1}{\pi^{2} \alpha_{\delta} B_{\delta} A_{a}}
$$

And it is similar to formula (8). As a result, both the synchronous machine, with electromagnetic excitation and reluctance machines mass determine equation (8).

\section{CONCLUSION}

1) analyzed electromechanical battery (EMB) main electrical machine types, and machines mass equations; 2) EMB used synchronous machines: electromagnetic 
excitation, with permanents magnets on rotor and reluctance machine.

\section{REFERENCES}

[1] Ледовский А.Н., "Проектирование кинетических аккумуляторов электрической энергии", Электричество. - 1983 - Nr 6. - (31 - 37).

[2] Ледовский А.Н., Литвинов И.И., Новиков М.Э., Тимофеев А.Т. "Проблемы создания кинетических аккумуляторов электрической энергии”, Электричество. - 1978. - Nr 3. - (41 45.).

[3] Power Bridge PILLER, Available: http://www.piller.com [Accessed: Jun. 22, 2010]

[4] The AFS Trinity Power Corporation, Flywheel Energy Storage System, February 2004

[5] A. Rojas - Flywheel energy matrix system - today's technology, tomorrow's energy storage solution. Available: http://www.BeaconPower.com [Accessed: Sept. 5, 2010]

[6] Battery-free UPS Energy Storage. Available: http://www.pentadyne.com [Accessed: Nov. 12, 2010]

[7] ENERCON WIND-DIESEL AND stand-alone SYSTEMS. Available: www.enercon.de [Accessed: Sept. 9, 2009]

[8] Direct Connect VDC140. Available: http://www.vyconenergy.com [Accessed: Nov. 6, 2010]

[9] Dynamic Uninterruptible Power Supply. Available: http://www.kstechniques.com [Accessed: Dec. 7, 2010]

[10] Д. А. Бут, Б. Л. Алиевский, С. Р. Мизюрин, П. В. Васюкевич. Накопители энергии. - М.: Энергоатомиздат, 1991

[11] Д. А. Бут - Бесконтактные электрические машины - М.: Высш. Шк., 1990

[12] Д.А. Завалишин, С.И. Бардинский, О.Б. Певзнер, Б.В. Фролов, В.В. Хрущев - Электрические машины малой мощности - М. Л., Госэнергоиздат, 1963

[13] Л.М. Пиотровский - Электрические машины - М. - Л., Госэнергоиздат, 1963

[14] H. Hofmann, S.R. Sanders - Synchronous Reluctance Motor / alternators for Flywheel Energy Storage System, IEEE 199-206, 1996

[15] Е.В. Кононенко - Синхронные реактивные машины - М., Энергия, 1970

[16] А.И. Вольдек - Электрические машины - Л., Энергия, 1974

A. Podgornovs received the B. Sc. ing. (2001), M. Sc. ing. (2004) and Dr. sc. ing. (2009) degrees Rigas Technical University, Riga, Latvia, all in electrical engineering.

Work experience: Rigas Technical University, LECTURER ELECTRICAL APPARATS AND MACHINES, LECTURER MATH METHODS COMPUTER REALISATION, LECTURER ELECTRICAL MACHINE MAGNETIC FIELD CALCULATON, Riga, Kronvalda bulv. 1. Research interests: synchronous motor self excitation using third harmonic of a magnetic field, electrical machine field calculations using finite element method.

Contacts: phone.67089929, e-mail: unic@inbox.lv

A. Sipovichs received the B. Sc. ing. (2008), M. Sc. ing. (2010) degrees Rigas Technical University, Riga, Latvia, all in electrical engineering.

Research interests: electrical machine design and choce methods for kinetic energy storage in city electrical transport network, electrical machine automated design

Contacts: phone. 29623208, e-mail: ant09ons@inbox.lv 